\title{
DICKENS IN BYRON'S CHAIR: AUTHENTICITY, AUTHOR PORTRAITS, AND NINETEENTH-CENTURY VISUAL CULTURE
}

\author{
By Mary L. Shannon
}

DICKENS'S COMIC ACCOUNT OF a charity dinner for the "Indigent Orphans' Friends Benevolent Institution" in his sketch "Public Dinners" (Sketches by 'Boz') is illustrated in the 1838 serial and 1839 volume editions with the image in Figure 2.

On first glance it portrays only the "indigent orphans" being marshalled in the dining room by "fourteen stewards, each with a long wand in his hand like the veiled genius of the pantomime" (Dickens, "Public Dinners" 165-66). ${ }^{1}$ But on closer examination we can see that two of the "stewards," standing to the left and right, are the likenesses of the sketch's author and illustrator, Charles Dickens and George Cruikshank. Early readers might have recognized Cruikshank from previous self-portraits in his popular work; some could have been able to identify 'Boz' from Cruikshank's illustration to "Early Coaches" (Sketches), from Hablôt Browne's image of him as the editor of Bentley's Miscellany, from the 1837 Laurence portrait (published as a lithograph in 1838) or from the 1839 Maclise portrait (published in Nicholas Nickleby). ${ }^{2}$ However, many first readers were unsure if the Maclise frontispiece was supposed to be 'Boz' or Nicholas, and Dickens's image only really became widely known and distributed in the 1850s once he began his Public Readings, despite his numerous representations in the popular press (Andrews 156). ${ }^{3}$ Cruikshank's visual in-joke reveals a concern with the authenticity of the illustration - 'we', the two portraits say, 'were there'. But it also picks up on an uncertainty regarding authenticity already present in Dickens's (originally un-illustrated) sketch. 'Boz' strides out confidently, hand on hip, but he glances back to the more-established Cruikshank for reassurance. 'Our readers may not recognise me', he might be saying, 'but they should surely recognise YOU. Won't they?'

This image of 'Boz' is part of the gradual evolution of Dickens's image and persona as a professional author; of the establishment and evolution of his "brand," to use a term employed by Robert L. Patten, amongst others. ${ }^{4}$ This was often at the expense of the very illustrators with whom he collaborated. ${ }^{5}$ As Gerard Curtis remarks:

Dickens, who downplayed his original partnership with illustrators like Seymour and Cruikshank in favour of promoting his own text, achieved the planned triumph of text over image after having used that very imagery to promote himself. (195) 


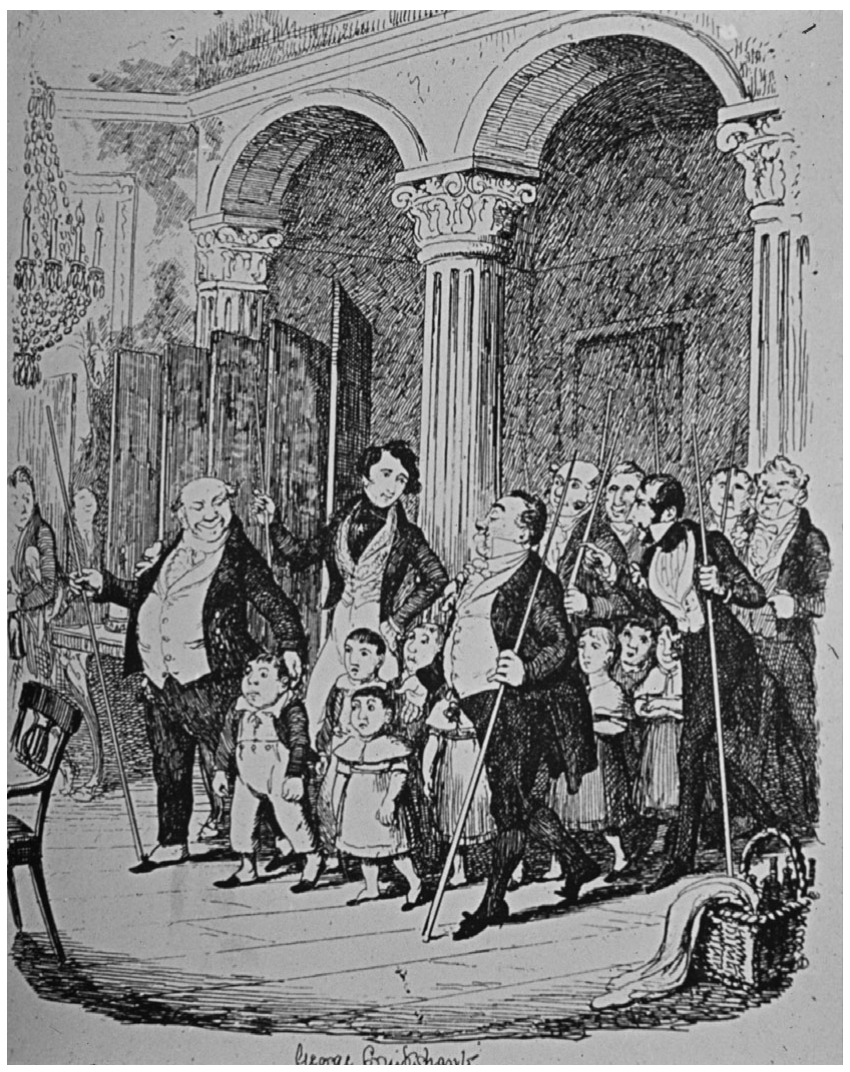

Figure 2. George Cruikshank. Public Dinners. Illustration from Sketches by Boz. Reproduced by permission of the Charles Dickens Museum, London.

Dickens is a key example of "the rise of celebrity culture in the Victorian period" (Marsh 98, 102), but it was not just advertisers and lionizers who made Dickens's face so well-known and widely circulated: Curtis shows how Dickens himself used visual culture to enhance his own status as a writer. There has been less work done, however, on where exactly these visual strategies might have come from, and what Dickens's relationship to earlier models might add to our understanding of nineteenth-century conceptions of celebrity and mass culture in general, and Dickens and authorship in particular.

I want to suggest that visual Byronism, together with Pierce Egan and George and Robert Cruikshank's Life in London (1820-21), provided successful examples of a visual iconography of male authorship and the creation of a public persona which Dickens and his artists drew upon in ways which developed Dickens's authorial identities. Utilization of the creator's image within and without a product was a widespread phenomenon of $1820 \mathrm{~s}$ and 1830s popular culture. Before copyright law, such images made a bid for authenticity: the genuineness of the work as the product of a particular creator (signatures on title pages made similar claims, although these, like author portraits, were often faked). Authenticity 


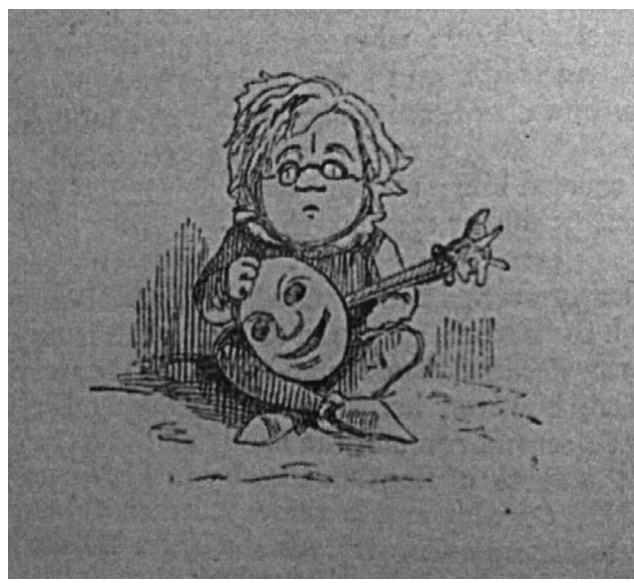

Figure 3. W. M. Thackeray. The Narrator Unmasked. Illustration from Vanity Fair (1848). @ British Library Board. C131.e.15.

was a concept ambiguously deployed in a literary culture where popular characters could be lifted from one context into another with no legal redress. But authenticity also carried the meaning in the period of verisimilitude, of being 'true to life' ("authenticity, n." $O E D$ ). This is a different kind of authenticity; author and artist images in popular texts and prints were frequently an attempt to verify their participation in popular culture, something which they could lay before their readers as a shared experience. Dickens's evolving authorial image emerges out of this context: Dickens learned about authorial 'branding' and brand maintenance from an earlier literary generation - it is not just Cruikshank that he is looking back at over his shoulder.

Visual Byronism and the Life in London craze both complicated the commonsense distinction that authors had bodies while fictional characters did not, just as 'Boz' was both a character and an author's pen-name. Representations of Dickens as an author have their antecedents in imagery drawn from popular canonical and non-canonical texts of the earlynineteenth century, and from visual traditions which, as Brian Maidment has shown, "retained a continuing appeal for many Victorians" (226) and were reformulated by early Victorian artists for a new audience (14). Images of Byron, and of Tom and Jerry, were everywhere in that period: it would have been impossible for an enthusiast for both London and popular culture, as Dickens was, not to have seen this. Alongside these were images and merchandise of popular theatrical characters such as Paul Pry and Dusty Bob (originally a Cruikshank brothers creation from Life in London), who broke loose from their original representations to gain bodies and lives of their own, as Pickwick did later (Vincent; Maidment 216-8). But in building upon these earlier models, Sketches also includes visual images of readers and rhetorical techniques which seek to link the body of the writer to the body of the reader.

From Sketches onwards Dickens frequently addresses his readers as if they are an intimate friend, ${ }^{6}$ and "Dickens's image, as it were, promised every member of his public a piece of him" (Marsh 106). The image of Dickens as 'Boz' in Public Dinners is very different from that of Thackeray the author/illustrator as the 'Narrator' in Vanity Fair (1848, Figure 3). Although 
similarly emphasising "the relation between image and text as one of self-conscious dialogue" (Fisher 61), Thackeray's drawing uses his characteristic metaphors of authorial identity as clown and mask at a time when, successful at last, he can parody himself (Carlisle 35-9). In Sketches Dickens does not yet have this level of control either of his career or his own image, ${ }^{7}$ and by the 1840 s Dickens was jettisoning his youthful persona (Patten, "Boz" 326 8). However, visual images of the author's body helped to differentiate Dickens from his pre-Victorian models as he attempted to create a relationship with his readers through print: a relationship necessarily intangible, imagined, and disembodied in an age of mass culture.

\section{Visual Byronism and the author's body}

DICKENS'S FIRST FORAYS INTO publication were under the pseudonym 'Boz', drawn from the childhood nickname of his younger brother. ${ }^{8}$ In writing to negotiate the terms of his editorship of Bentley's Miscellany, Dickens made it clear that he was aware of how much "assistance the 'Boz' name just now, would prove to the circulation" (Dickens to Richard Bentley 190); 'Boz' had developed into a famous and lucrative tag, with a value to his publisher all of its own. Sketches and tales in a similar tone to Dickens's came to be known as 'Bozzes'; plagiarists and imitators such as T. P. Prest published under versions of the 'Boz' name such as 'Bos' or 'Poz' - and " 'Boz' came to name a genre as well as an author" (Patten, “Boz” 76). Dickens's anonymity did not last long, ${ }^{9}$ and he was well aware of the cultural power of the image of the writer's body. In the early 1840s the young Dickens collaborated with his illustrator George Cattermole over The Old Curiosity Shop and Master Humphery's Clock. Dickens visited Cattermole's house in Clapham Rise for convivial gatherings, and was sketched by Leonardo Cattermole, seated in Byron's chair (Figure 4). There are several early sketches of Dickens in chairs, some of which were published, ${ }^{10}$ but this chair was special: George Cattermole brought it from his old chambers in Albany, which had once been occupied by Byron (Slater 145 and plate 35; Cohen 125, 131, 257 n. 55). Leonardo Cattermole's sketch of the young Dickens energetically gesturing and talking links the image of 'Boz' and the writer's body to Byron himself, through the inanimate object of Byron's chair. Byron was such a potent early-nineteenth century cultural icon that his chair is enough to suggest his presence, but more importantly his absence: an absence filled, the sketch suggests, by a new literary celebrity in the form of Dickens. ${ }^{11}$

As early as the 1820s we find the phenomena of Byronism - created out of Byron, his poems, his life, his reputation, his portrait and his image - which turned Byron into a celebrity different in scale from anything that had gone before. Byron was not only one of the first literary celebrities in our modern sense of the word, but "it was Byron's image that was a key element of his cultural impact" (Mole, Byron's Romantic Celebrity 79). Scott played a key role, of course, in early-nineteenth century conceptions of authorship (and for Dickens in particular), but Byron was important for a particular kind of visual iconography of celebrity authorship. ${ }^{12}$ People read Byron, sighed over Byron, and imitated Byron: St Clair provides the anecdote of the fashion writer, who in 1828 published a book on The Art of Tying the Cravat, which included a plate to illustrate the "cravat à la Byron"(The Reading Nation 333). Dickens would almost certainly have been aware, as a precocious boy of twelve, of Byron's death in 1824.

What St Clair calls "visual Byronism" ("Towards a Political Economy of Book Illustration") - the volume of, and fascination with, images of Byron - extended beyond 


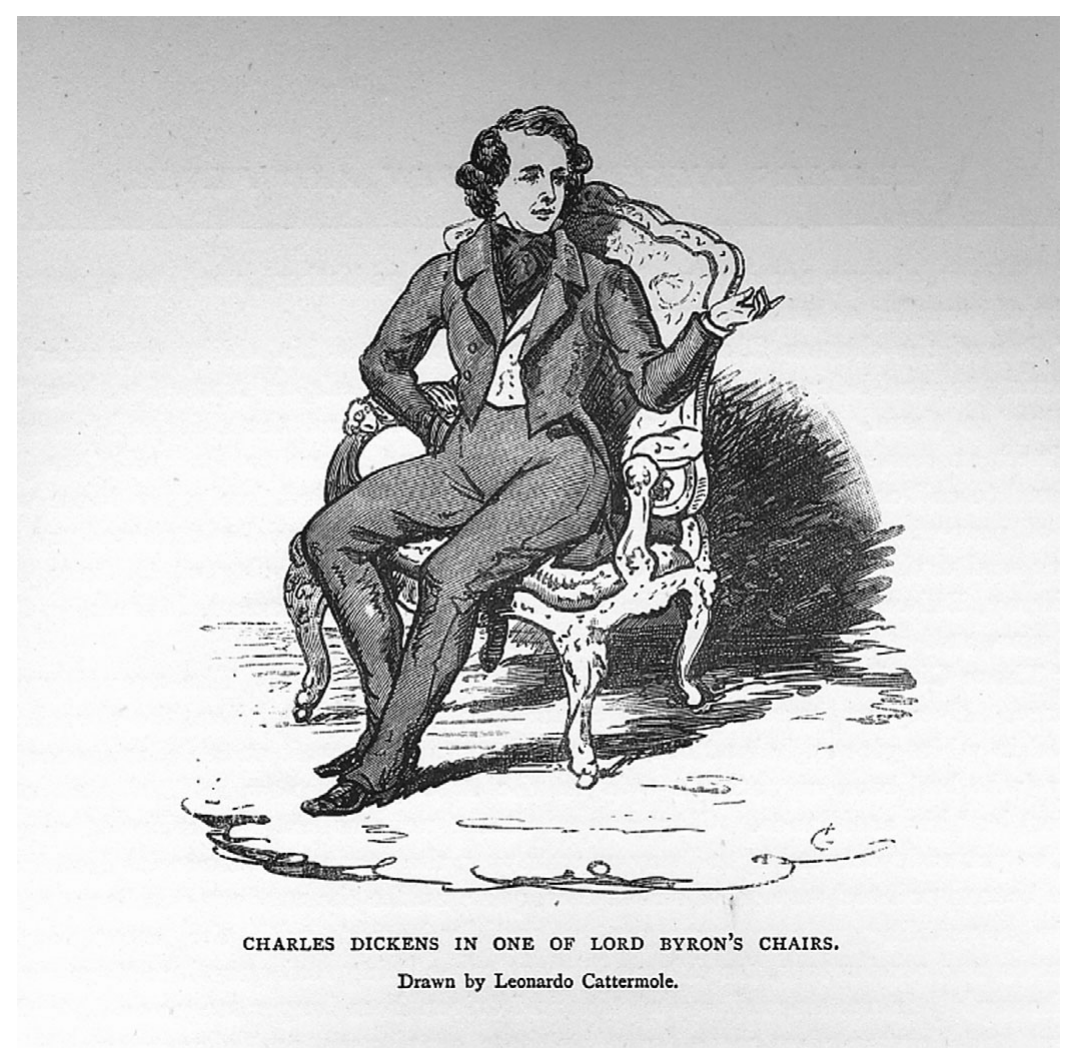

Figure 4. Leonardo Cattermole. Charles Dickens in one of Lord Byron's Chairs. Reproduced by permission of the Charles Dickens Museum, London.

Byron's lifetime into the 1830s, and it was of course "the portrait of Byron, around which was built the legend of Byron as the romantic hero of his own / poems" (St Clair, Reading Nation 331-32). Images of Byron, authorised and unauthorised, circulated widely and could be put to various uses: as prints to hang on a wall, as images for a scrapbook or album, or as frontispieces to texts. Portraits of Byron were included with his poetry so that the author's body was part of the reader's experience of the text. ${ }^{13}$ Byron was "cannily complicit" in this propagation of his image, commissioning portraits by Richard Westall and Thomas Phillips which became the basis of the majority of popular illustrative portraits and prints (Mole, Byron's Romantic Celebrity 81; Figures 5 and 6). The key signifiers of Byron's image were quickly established, so that "he could be represented by just a few conventional markers, and yet still be unmistakeable" (Byron's Romantic Celebrity 97). 'Boz' also developed key markers, which emphasized his youthful energy. There is a touch of Byron in Dickens's love of smart dressing: Cattermole's sketch emphasizes the soft hairstyle, pale waistcoat and dark cravat of 'Boz', as does Cruikshank's Public Dinners.

As well as these individual portraits, visual Byronism emphasized another particular kind of authorial image, one where the writers merged with their characters so that Byron's 


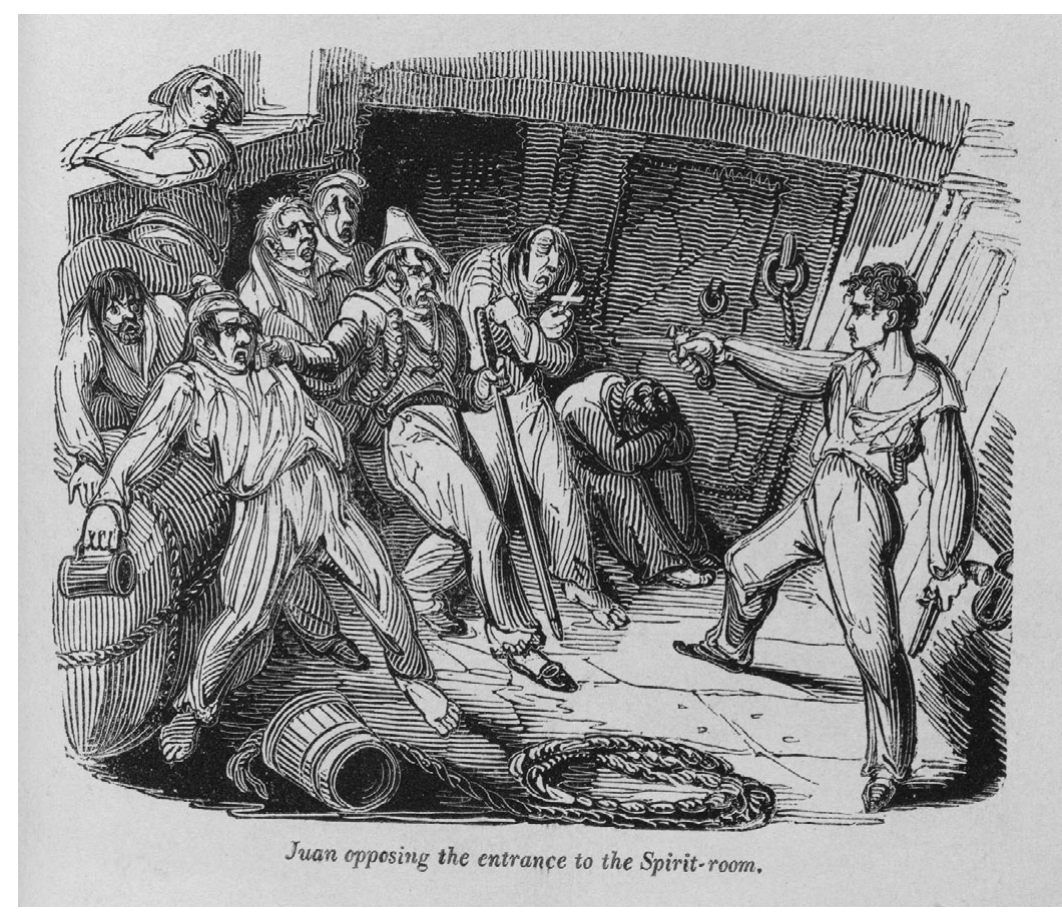

Figure 5. George Cruikshank. Juan opposing the entrance to the Spirit-room. Illustration from Forty Illustrations of Lord Byron. $19^{\text {th }}$ leaf. London: James Robins and Co. [1825]. British Library. Also reproduced in Mole, Byron's Romantic Celebrity.

image and the so-called 'Byronic hero' became synonymous. Byron projected the Romantic focus on subjective emotions and the inward self, outwards into a dramatic persona: the melancholy disillusioned wanderer (Childe Harold's Pilgrimage (1812-16)); the passive innocent in a fallen world (Don Juan [1819-1824]), and the exotic traveller (his Oriental tales and heroic death in Greece). Byron was both Childe Harold and Don Juan. George Cruikshank's illustration to Don Juan, from a set of woodcuts produced just after Byron's death, is a recognizably Byronic representation of Byron's hero which draws upon the Westall portrait (Figures 5 and 6), as Mole has pointed out (Byron's Romantic Celebrity 90-91). Byron's head is placed upon a sexualised body. In visual Byronism the male celebrity author becomes a cultural object which participates in the world of his characters, his body made part of the cultural consciousness through the mass distribution of his image. ${ }^{14}$

Dickens both makes use of the tropes of Byronic authorship, and draws careful distinctions between Byronic celebrity (and scandalous notoriety) and his own relationship with his readers. The craze for visual Byronism is frequently mocked in Dickens's writing. His young male characters often exhibit alarming tendencies to fancy themselves as Byronic heroes, complete with the requisite floppy hair, loose cravat, and dreamy gaze: an obvious example is Horatio Sparkins, from Sketches by Boz, "with his hair brushed off his forehead, and his eyes fixed on the ceiling," whose elegance moves Miss Teresa to murmur "How like Lord Byron!" but who turns out to be nothing more glamourous than an assistant in a draper's 


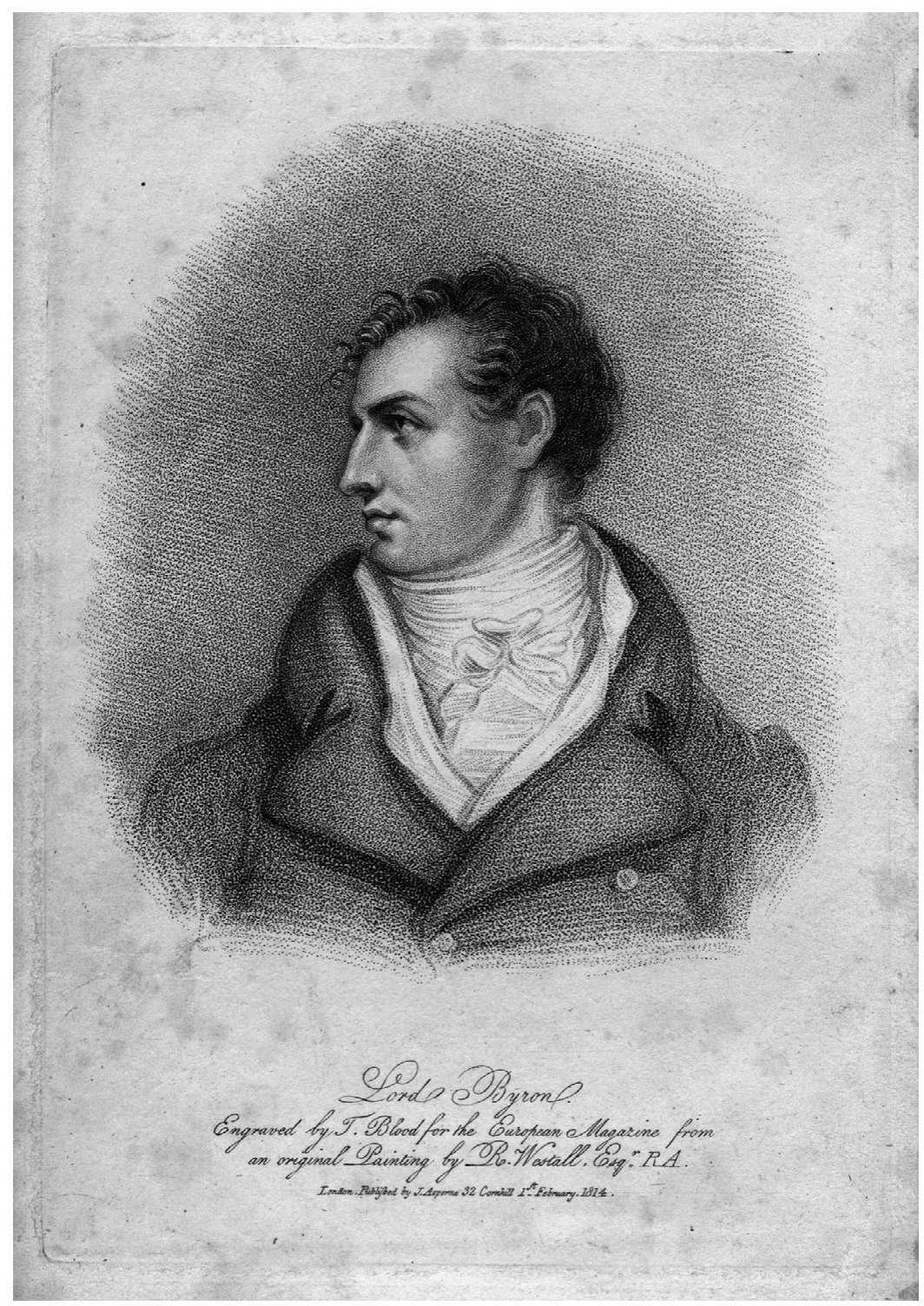

Figure 6. Thomas Blood after Richard Westall. Byron. Engraving. European Magazine (Jan. 1814). (C) National Portrait Gallery, London. Also reproduced in Mole, Byron's Romantic Celebrity.

shop (Dickens, "Horatio Sparkins" 348). ${ }^{15}$ This very mockery registers the power of Byron's image. Later, of course, Dickens begins to add a different kind of Byronic hero to his fiction, notably Steerforth in David Copperfield. But in mocking young men like Horatio Sparkins, Dickens is also mocking himself: Cruikshank's illustration of Horatio Sparkins looks rather 
like his pictures of 'Boz'. In Dickens's travelogue Pictures from Italy, a waiter in Bologna is mocked by Dickens for being "A Great Admirer of Lord Byron":

I made the discovery by accidentally remarking to him, at breakfast, that the matting with which the floor was covered, was very comfortable at that season, when he immediately replied that Milor Beeron was much attached to that kind of matting. Observing, at that same moment, that I took /no milk, he exclaimed that Milor Beeron never touched it. At first I took it for granted, in my innocence, that he had been one of Lord Beeron's servants; but no, he said, no, he was in the habit of speaking to English gentlemen about Milor Beeron; that was how he know all about him. . . . He ran briskly up-stairs again, I dare say to tell some other Englishman in some other solitary room that the guest who had just departed was Milor Beeron's living image. (72-73)

Dickens shows his awareness here of how Byron's literary celebrity floats free from his physical body and even from his works. For all that Dickens turns this literature-loving waiter into a figure of fun, he is also not averse to linking his own image to that of a writer whose brand of 'Byronism' circulates so widely in culture. ${ }^{16}$ Dickens's own sudden rise to fame was compared by the Quarterly Review in 1839 to that of Byron. ${ }^{17}$ The sketch of Dickens in Byron's chair - with its emphasis on Dickens's flowing hair and self-consciously literary pose - is more than a tacit (if less sexualized) homage to Byronic portraits: Cattermole positions Dickens, or 'Boz', as a successor to Byron, who has literally taken Byron's seat in the gallery of literary celebrity. ${ }^{18}$ At the same time, Dickens's own textual references to visual Byronism point to the importance of readers in the creation of celebrity authorship. Horatio Sparkins, Miss Theresa, and the Bologna waiter are, one imagines, all readers of Byron as well as consumers of his image.

The circulation of Byron's image separated his physical body from his celebrity, and placed him in the same world as his characters. Images of Byron at the front of editions of his work became a bid for authenticity, as the author portrait was used by unscrupulous publishers to authenticate plagiarized editions (St Clair, Reading Nation 332). Images of 'Boz' in publications, either written or edited by the young Dickens, also gave significance to the body of the author. An advertisement included in the third number of Bentley's Miscellany shows 'Boz' leading the Miscellany forward, as delighted readers snatch eagerly at copies that have fallen from the pile (Figure 7). The editor portrait serves as a stamp of authenticity, that this is a genuine production of the 'Boz' brand, and of 'Boz's' own 'body'(although in a move beyond visual Byronism, this image emphasizes the importance of the readers by including depictions of readers' bodies, too). ${ }^{19}$ Again we see 'Boz' marked out by his clothes and his energy. Cruikshank's illustration Public Dinners places the writer within the scene as a marker of a different kind of authenticity. It is the graphic equivalent of 'Boz's' narrative voice in the sketch itself, which addresses the reader directly in the present tense, as if they are a familiar friend:

Let us suppose you are induced to attend a dinner of this description - 'Indigent Orphans' Friends' Benevolent Institution,' we think it is. The name of the charity is a line or two longer, but never mind the rest. (162)

The joke here rests on the reader having seen advertisements for such charities, and knowing the nineteenth-century convention for very long charity names. But it also reassures (and flatters?) the reader that 'Boz' is just like them, the kind of middle-class gentleman who would be invited to such events, and knows the conventions so well that he can skewer 


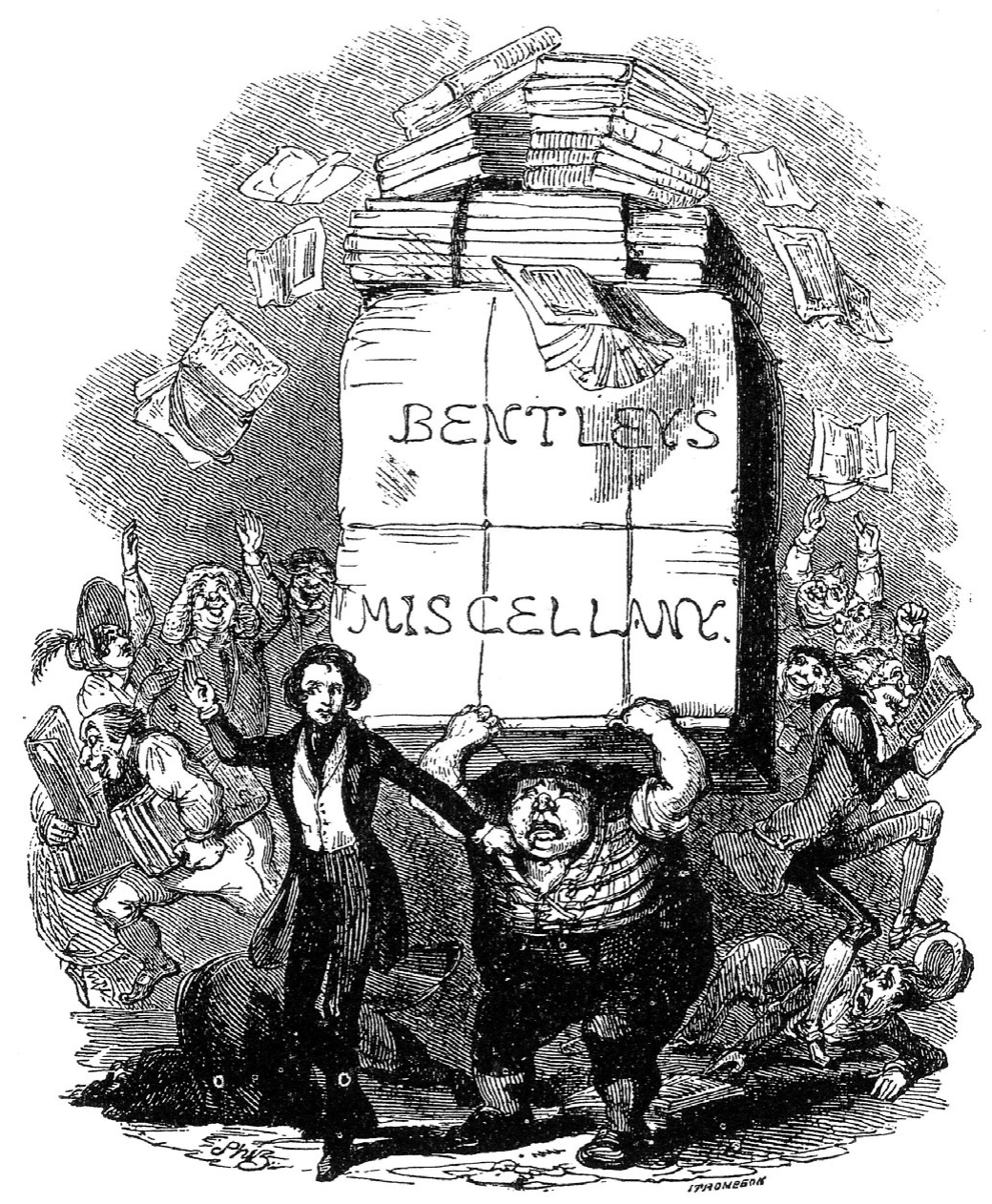

Figure 7. Hablot K. Browne. Publishing Day of “Bentley’s Miscellany.” 1837. Charles Dickens Museum, London.

their pretensions successfully. It conscripts the reader onto 'Boz's' side just as much as the conspiratorial "let us suppose," and the informal "never mind the rest." Dickens ends "Public Dinners" by aligning his own writing with the event which he has described, and so connects the reader to 'Boz' the writer and 'Boz' who is a character in the sketch, in a complex web of fiction and reality:

We have protracted our dinner to so great a length, that we have hardly time to add one word by way of grace ... (167)

'Boz's' royal "we," the voice of the newspaper correspondent, puts him at the scene of the action, like a wiser version of Horatio Sparkins himself. Richard Sha argues that the sketch 


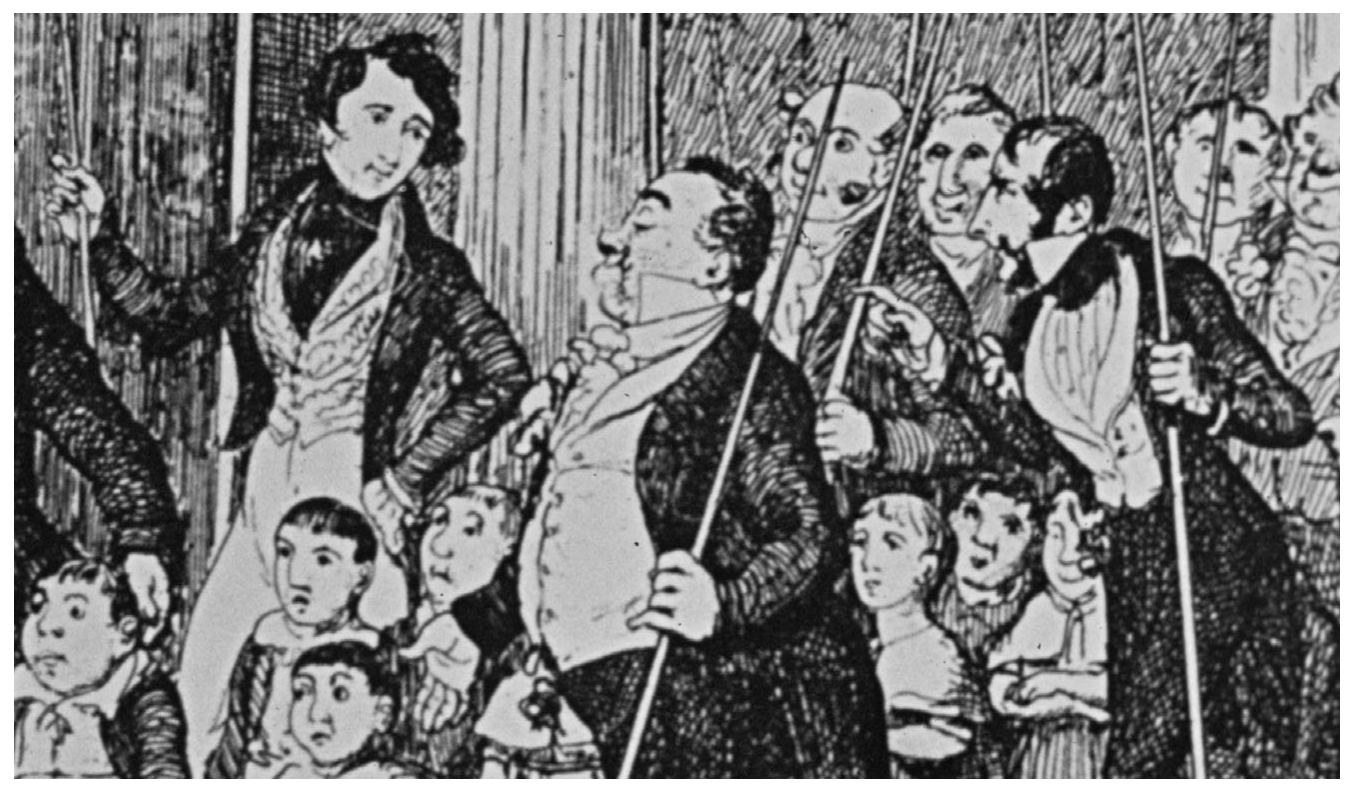

Figure 8. George Cruikshank. Public Dinners (detail). Charles Dickens Museum, London.

form (whether visual or verbal) presents its rushed incompleteness as a marker of truthfulness; that it creates an "ideological rhetoric of denied rhetoricity" in order to posit authenticity (Sha 1). Dickens's "Public Dinners," however, is highly rhetorical, and uses this very rhetoricity alongside its illustration to stake its claim to 'Boz's' authentic participation in London life.

The use of "we" here points to an important difference between Cruikshank's representation of the body of 'Boz' and images of Byron's body. While images of Byron sanctified the role of the individual literary lion, albeit often without his direct sanction, in Public Dinners Cruikshank emphasizes the collaboration between writer and illustrator (Figure 8). To the right of 'Boz' as we look at the image stands Cruikshank himself, with his distinctive nose and forward-swept 'Brutus' hairstyle. 'Boz' may be striding out slightly ahead of Cruikshank in the procession, but his attention is being recalled by the artist who is leaning forward, pointing out to the writer something of interest in the scene. When you look closer, you see that 'Boz' is only slightly ahead of Cruikshank because of the perspective: in fact, they are level. The point is clear: the writer may be the starting-point for these sketches, but the input of the artist is crucial to their reception, too. No longer is writing the preserve of the lone Romantic genius. ${ }^{20}$ The term "sketches" already implies a close relationship between graphic art and the written word: ${ }^{21}$ in this illustration Cruikshank underscores the team effort required for this popular literary form. In so doing, Public Dinners points to what I am proposing as a second key influence on the creation of 'Boz', the Life in London craze.

\section{The Life in London craze}

IT WAS NOT JUST AUTHOR portraits that provided a precedent for the development of 'Boz': Cruikshank's care and promotion of his public persona as an artist was another useful model 
for the young Dickens. ${ }^{22}$ In Cruikshank's frontispiece to the Second Series of Sketches by Boz, published in December 1836 in one volume, writer and artist are embodied as balloonists setting forth, one presumes, to soar across London and to take the reader on a panoramic flight over the city (Figure 9). Significantly, as with Bentley's Miscellany, this illustration places readers at the opening of the volume: in a tacit recognition of market forces, the imagined readers are as prominent as the celebrity author and artist, if not more so. Dickens used the reputation of the older and established Cruikshank to launch his own: he makes this clear in the Preface to the first edition of the First Series (containing "Public Dinners"), in which he describes the volume as "a pilot balloon," an image which Cruikshank clearly drew upon for his Second Series title page:

Entertaining no inconsiderable feeling of trepidation at the idea of making so perilous a voyage in so frail a machine, alone and unaccompanied, the Author was naturally desirous to secure the assistance and companionship of some well-known individual ... To whom, as possessing the requisite in an eminent degree, could he apply but to GEORGE CRUIKSHANK? (Dickens, Preface xxxix)

Notice the use of capitalisation here, which reproduces Pierce Egan's invocation to "GEORGE CRUIKSHANK (thou Gilray of the day)," at the start of Life in London (11).

Cruikshank developed a public persona through the careful placement of his own image: one only has to glance through George Soames Layard's 1897 book George Cruikshank's Portraits of Himself to see that Cruikshank's self-portrait crops up time and time again in his work (Layard). With his fashionable dress, Regency haircut and distinctive nose, Cruikshank was a readily recognisable figure, as Layard shows. In the illustration Public Dinners, 'Boz' and his illustrator are placed not only within a tradition of author portraits exemplified by visual Byronism, but also within the context of Cruikshank's self-portraits as an artist. And in its representation of both writer and artist within the world of their characters, the image also places 'Boz' and Cruikshank - and therefore Sketches by Boz as a whole - in a direct line of descent from Cruikshank's previous collaborations with a London author, in Life in London (1820-21). Significantly, Sketches also shows the marks of Life in London's interest in the presence of readers as author and artist reach out to the consumers of a new emerging mass culture.

Even though 'Boz' is most interested in the middle classes, while Egan ignores them almost entirely, it seems clear from Sketches that Dickens was well aware of Life in London, and was in many ways writing against it (unsurprising given its manifold representations in popular culture of the $1820 \mathrm{~s}$ and 30s). ${ }^{23}$ Dickens was quick to distance himself from Egan's Regency raffishness precisely because the comparison was so obvious, and he gradually shifted the persona of 'Boz' over the 1830s from insouciant gent to family author (Schlicke 263-64). At the same time, images of Dickens as 'Boz' in both Sketches and Bentley's Miscellany drew upon a Regency visual culture already exploited by Egan and the Cruikshanks. Life in London was a text by the sporting writer Pierce Egan, with illustrations by his friends and drinking companions George and Robert Cruikshank. It was first published in phenomenally successful monthly parts, like the appearance of Pickwick sixteen years later. The plot, such as it is, follows friends Corinthian Tom and Bob Logic as they take Tom's country cousin Jerry Hawthorn on sprees around London. It owes a lot to the tradition of London travel and conduct guides, which enlightened readers as to the metropolitan delights of booze, girls, and gambling, and where to find them. Life in London participated in a 


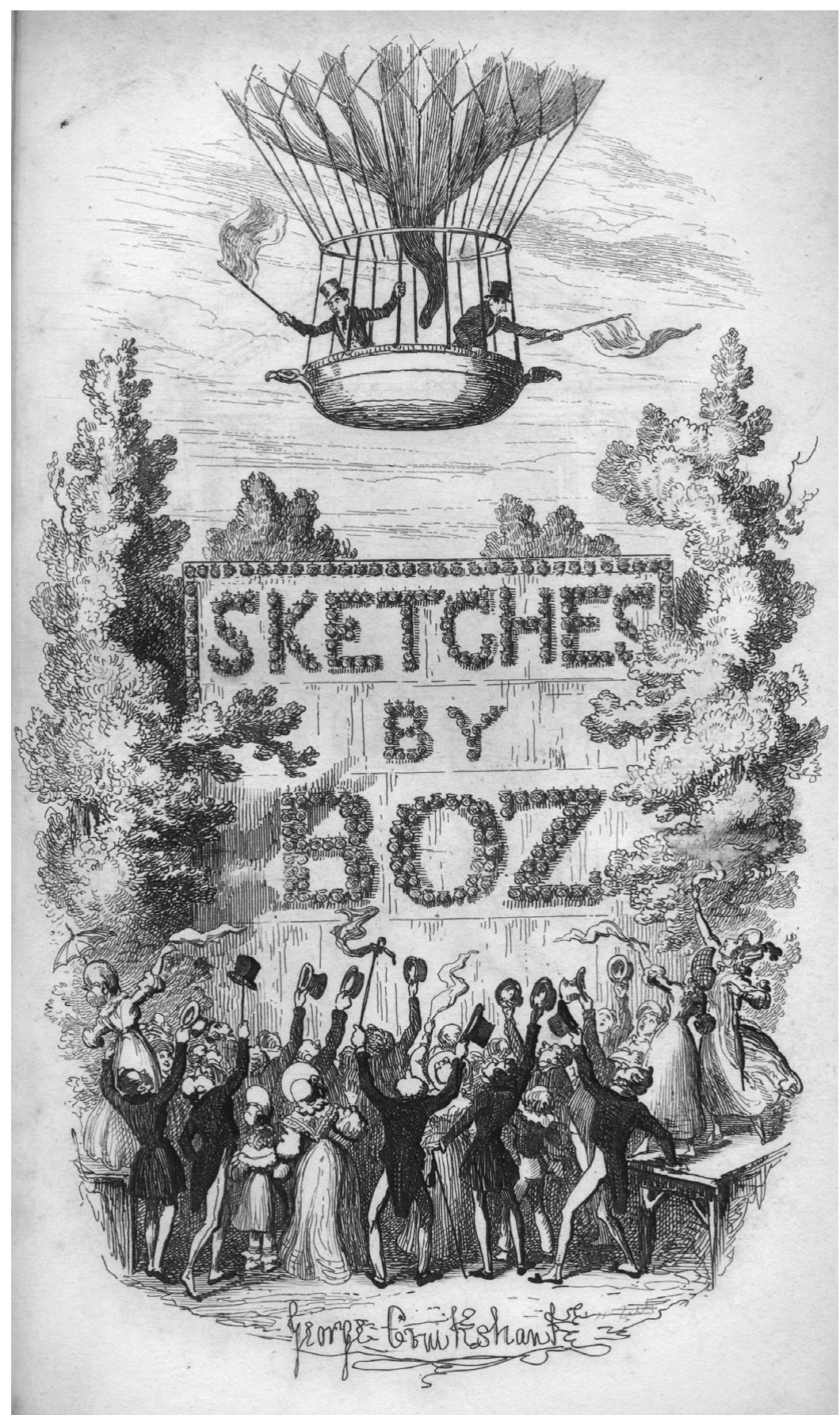

Figure 9. George Cruikshank. Title page from the 1836 Second Series of Sketches by Boz. Charles Dickens Museum, London. 


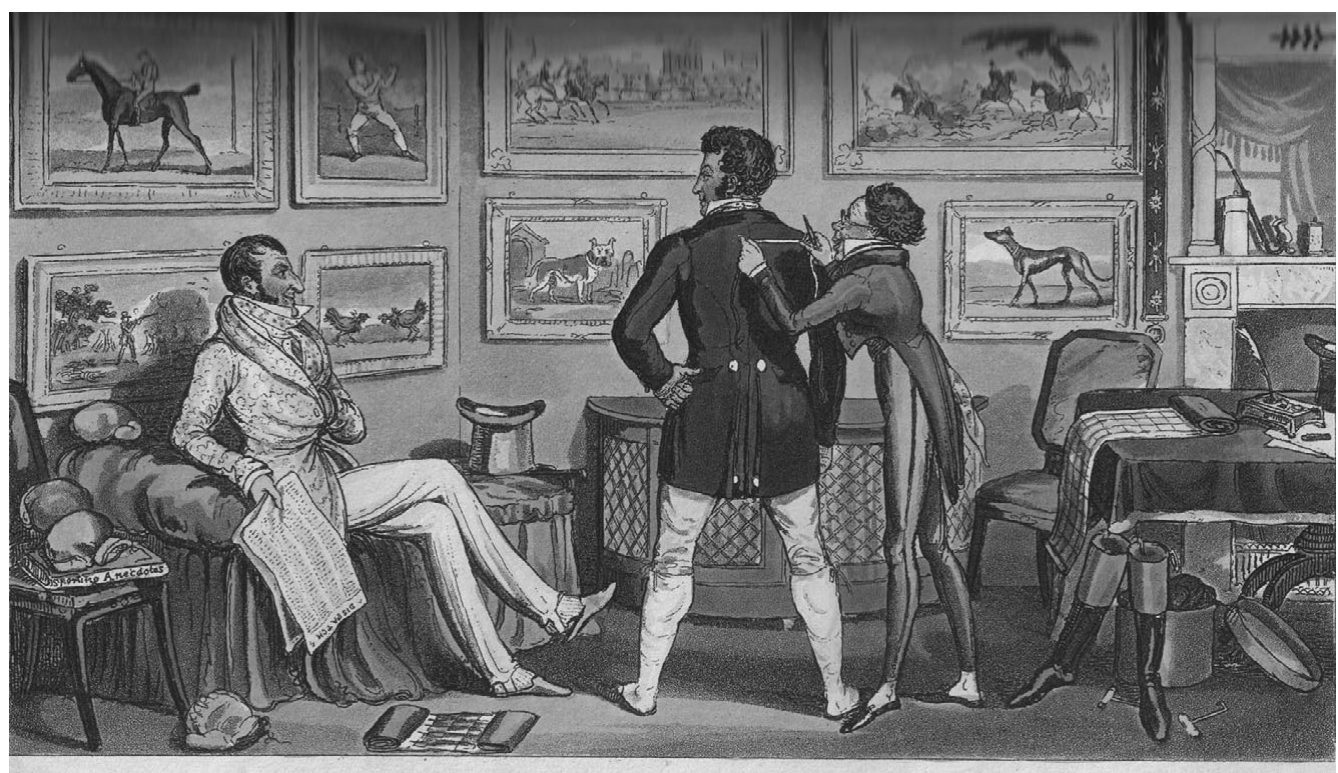

Drawn \& Engraved by I.R \& G.Cruichshant

Figure 10. Robert and George Cruikshank. Jerry in training for a "Swell." Illustration from Life in London (1820-1). All images from this text from a private collection.

visual culture in which popular characters such as Tom, Jerry, Dusty Bob, Paul Pry, and Dr. Syntax were appropriated into imitations and rip-offs in the form of theatrical adaptations, broadsides, prints, merchandise, and ephemera. ${ }^{24}$ Life in London, like aspects of visual Byronism, complicates distinctions between creators with physical bodies and characters without.

Egan, Robert, and George were identified in popular imagination with their three characters Bob Logic, Jerry, and Tom. With the character of Corinthian Tom in particular, we can see a marked resemblance to George Cruikshank, especially in the first plate (Figure 10). ${ }^{25}$ Robert L. Patten, in his biography of Cruikshank, goes so far as to say:

Corinthian Tom validated Corinthian George . . . No longer just a figure in a print attending Elias Carpenter's sermon or listening with the Radicals to Coriolanus in front of Carlton House portico, George could be the hand that etched the plate, the person whose exploits were inscribed by pencil and needle, and the character portrayed on a hundred stages. This was the high-water mark in Cruikshank's construction of a public self. (231)

Just as 'Boz's' and Cruikshank's presence in the Public Dinners illustration offers a guarantor of authentic participation in the described events, the persistent identification of Cruikshank and his fellow collaborators with Tom, Jerry and Logic (which they both denied but also played upon) sought to integrate writer and artists into the world of their creations. ${ }^{26}$ But I suggest that George Cruikshank turns up in Life in London as more than one of many possible models for Corinthian Tom. In Figure 11, Cribb's Parlour: Tom introducing Jerry and Logic 


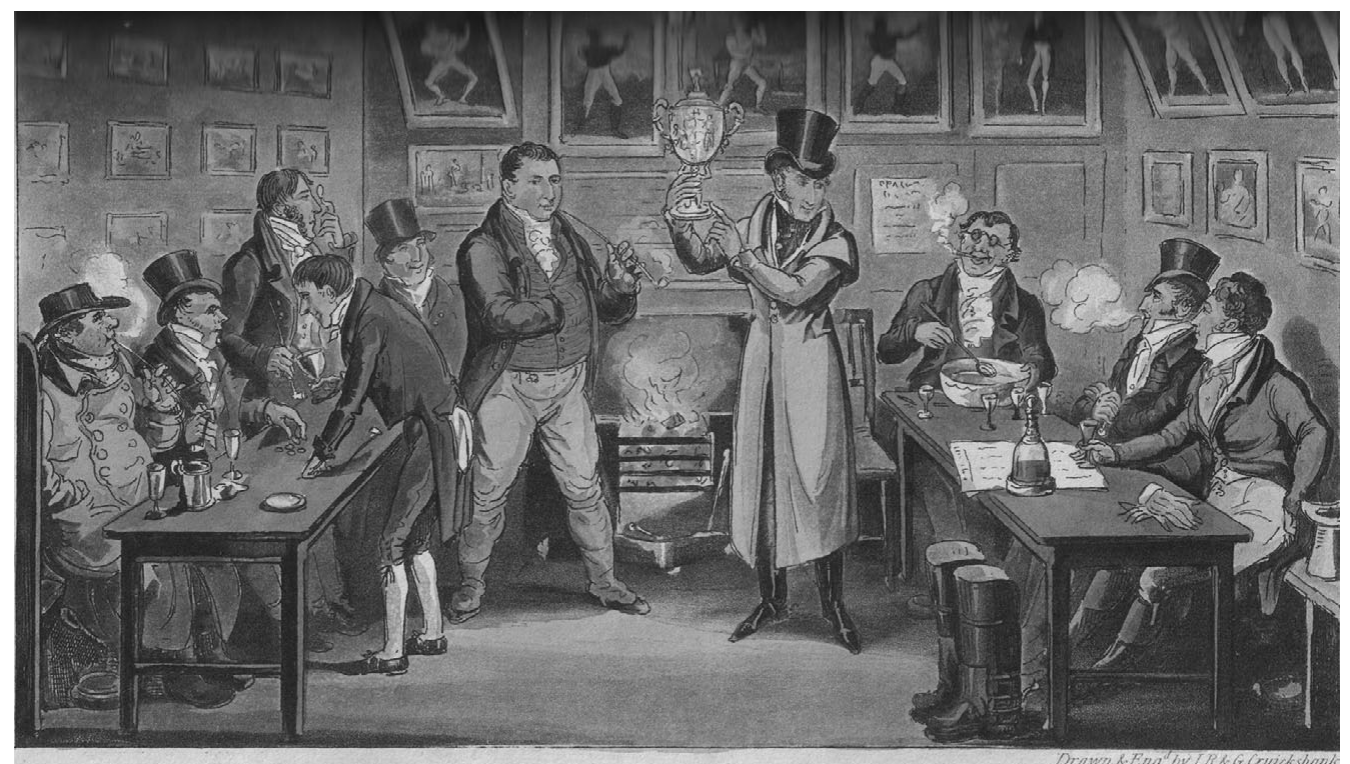

Figure 11. Robert and George Cruikshank. Cribb's Parlour: Tom Introducing Jerry and Logic to the Champion of England. Illustration from Life in London.

to the Champion of England, Tom in the centre is holding up Cribb's boxing trophy for Jerry and Logic, who are sitting at the table on the right. But who is sitting in-between them? George Soames Layard claims that the figure on the left, standing up with his quizzing glass to his eye in an exaggerated expression of interest in the trophy, looks very similar to George Cruikshank. Layard is correct that Cruikshank is present in this scene, but he is not stuck in obscurity stage-left. He is right in the middle of things, wearing a top hat and seated in between Jerry with his distinctive green jacket and Logic with his distinctive glasses, listening to Tom. This is a public self as fully part of the characters' adventures, a parallel reality where both characters and their creators can share representational space.

Egan's text collapses distinctions between writer and characters in ways which seem to anticipate Sketches by Boz; it was not just George Cruikshank who offered the young Dickens a useful model of how to develop a public persona. Pierce Egan inscribes writers and artists into the text of Life in London as part of a list of London "types" who are to be seen in Hyde Park, which Tom calls "the Show-shop of the Metropolis" (148), and he also makes viewing and reading - the activities of his readers - crucial to the publication, too. Tom describes the kinds of people they will meet in the park for Jerry's benefit, and includes "PAINTERS on the look out for characters, and Authors for the purpose of gaining a knowledge of real life" (152). "Real life" is important to Egan throughout Life in London, as he presents it again and again as an authentic depiction of London scenes and London people, and makes this its chief selling-point. Reading and seeing and knowing are conflated for Egan: experience of the city brings with it the ability to read its images aright; the worldly-wise Tom warns innocent Jerry that false beggars practise upon the busy city-dweller "in his hasty walks through the streets 
of London, who has scarcely time to "read as he runs"' (343). Life in London promises "a fine sketch of real life" (178), and this authenticity is achieved through visual images and visual imagery, which attempt to blur the distinction between reading the city and reading the text and images of the serial. This is very much a shared enterprise, a model for the collaboration shown in Public Dinners. Maidment has shown the complex interactions between visual and verbal forms in popular texts of the 1820s-50s, and Egan addresses the Cruikshanks directly in chapter 1:

I have need of all thy illustrative touches; and may we be hand in glove together in depicting the richness of nature ... that we may be found, en passant, so identified with the scene in question, as almost to form part of the group. (12)

Here Egan sanctions identification of writer and artists with their characters in the performance of a particular kind of sporting masculinity. As in visual Byronism, writer and characters participate here in a shared world. They are simultaneously all real and all fictional; they all have bodies, and all do not. This blurring of fiction and reality is used to guarantee the cultural authenticity of the text in ways which pre-figure Sketches.

The Public Dinners illustration of 'Boz' and Cruikshank not only places 'Boz' visually at the scene of the sketch, it places him visually within the volume itself. It stamps the author's mark on his work. Egan, too, stamps his own mark onto his text at the point where the material realities of authorship become pressing. He loses his pocket-book, which he refers to as his "reader," and so cannot deliver his full portion of weekly text, thereby risking the loss of his imagined "reader": here Egan's propensity for puns is brought into service of the need to apologize to purchasers of the serial. The plate which depicts the theft of the manuscript in a street fight tries to authenticate Egan's story (Figure 12). But it also tries to authenticate Egan's whole story, that is, Life in London itself, by showing the author unapologetically as a companion of his characters, part of their larks and sprees, sharing their world, "part of the group." Author and characters both have bodies here, and the reader is also given a presence in the text, even though their body is not represented in the image.

Peep ' $o$ day Boys is a wonderful visual image for an embattled author under pressure from thieves (Figure 12b); although this plate was issued perhaps slightly early in the serial publication of Life in London for many of the adaptations and imitations to have yet come out, rip-offs and dramatizations began emerging remarkably quickly. The stage productions reconstructed London sites in detail for the uninitiated, and there were even tours of the London landmarks in Egan's narrative. Egan took to the stage as Bob Logic in his own adaptation of Life in London at Sadler's Wells, which reproduced costumes and sets from the Cruikshanks's illustrations. ${ }^{27}$ Egan became like a living illustration of his own work; in a production which already represented the exasperated author's attempt to reclaim his own text back from appropriators like the dramatist W.C. Moncrieff, Egan sought to reclaim the visual images of his serial, too. As Dickens himself began to enjoy the dubious delights of fame and notoriety, he too famously suffered from unauthorized adaptations of his work. He employed similar strategies to Egan, co-operating with favoured productions, notably at the Lyceum in the early 1840s (Shannon 142-50), and he took to the stage in a curtaincall at the first night of his play The Village Coquettes in 1836 (Douglas-Fairhurst 231). Forster, reviewing the play for the Examiner, was annoyed by the curtain-calls; he mocked the way Dickens was paraded as "the real living 'Boz'." Forster reveals his own prejudices 


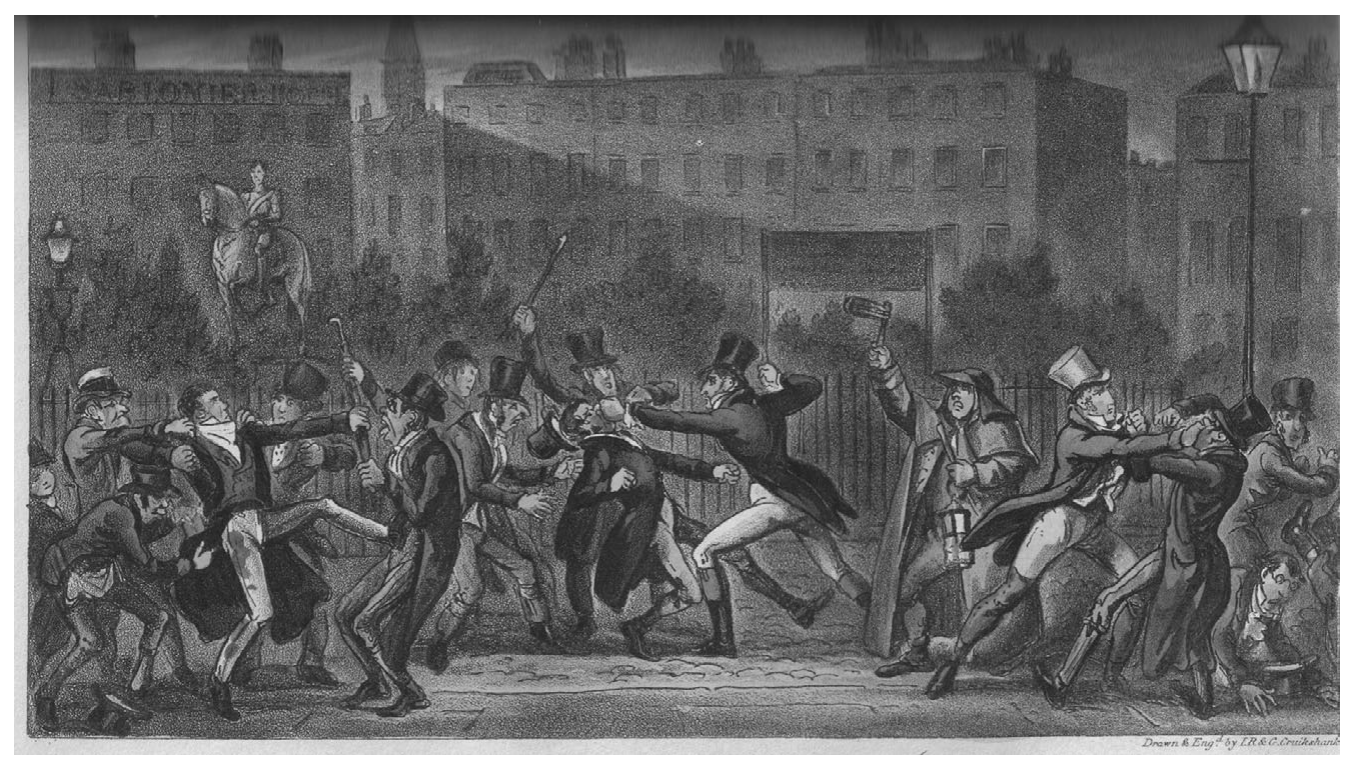

Figure 12a. Robert and George Cruikshank. Life in London: Peep 'O Day Boys. A Street Row. Illustration from Life in London.

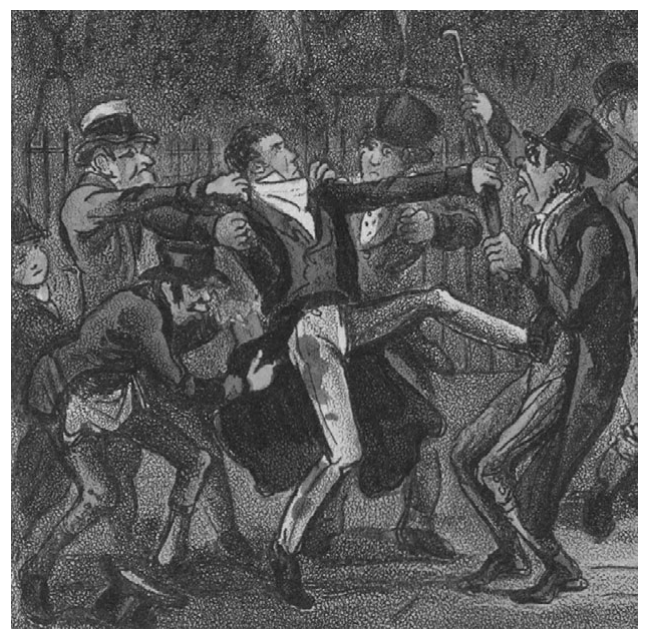

Figure 12b. Robert and George Cruikshank. Detail of Life in London: Peep 'O Day Boys. A Street Row. Illustration from Life in London.

against the commercial promotion of authorship here, but claims that the audience were upset that Dickens failed to look either like the 'Boz' they had envisaged or any of the Pickwick characters. Forster passes withering judgement on the theatre manager for encouraging this identification of author with characters by "exhibit[ing] a large wood-cut of Pickwick on 
his bills, with an intimation that 'Boz' will be shown nightly after the opera" ([Forster], "Theatrical Examiner" 231). At this stage in Dickens's career, the real-life body of the author (as opposed to its visual representation) seems problematic for a public which appears to expect a Byronic or Eganesque merger of author and characters.

By the time Dickens began his popular Public Readings, however, the distinction between the writer's embodiment through images of his body, and his live appearance on stage, did not appear to trouble the spectators of these Readings. By then, Dickens's reliance upon the 'Boz' brand had decreased, and he was publishing under his own name. Instead of an identification betweeen author and characters, Dickens's writings emphasized the link between author and readers, whom he addressed as if they were close personal friends. ${ }^{28}$ This style, already present in "Public Dinners," sought to co-opt the reader into the viewpoint of the writer and to reclaim the author's body for his readers and for himself.

\section{Dickens's Readers and the Writer's Chair}

DICKENS'S DESIRE TO DEVELOP the perception of a close personal relationship with readers though print has long been recognized: at his death, obituaries frequently accepted this disembodied friendship as a given. ${ }^{29}$ This impulse is already evident in Sketches by Boz. The relationship between text and image (and between different kinds of authenticity) is not straightforward in "Public Dinners": there is something very disorientating about where Dickens positions 'Boz' in the sketch as a whole. The language of the sketch makes as much of a bid for cultural authenticity as the illustration: it is stuffed full of details to convince (or flatter) the reader that 'Boz' has experienced the same frustrations as them during such events, and most of the humour relies on the reader recognizing themselves in the descriptions of "melancholy-looking saltcellars, and decayed vinegar-cruets," and cutlery which looks "as if they had done duty at every public dinner in London since the accession of George the First" (164). 'Boz's' understanding of these trials attests to his presence at such dinners. This means, however, that the personal pronouns become unstable, so the "you" of the reader merges disorientatingly with the "we" of 'Boz'. ${ }^{30}$ Where exactly is the 'authentic Boz' in this sketch? Is he one of the stewards in the illustration? Or is he amongst the diners, watching with the reader as the stewards process in? Dickens may be associated with his characters in the illustration to "Public Dinners," as the use of visual iconography recalls earlier precedents, but the text of "Public Dinners" points towards the important relationship Dickens would increasingly endeavour to create in the future: the one between writer and readers. ${ }^{31}$

Dickens's use of the personal pronoun "you" places the reader within the sketch too, as if sharing the body of 'Boz'. The viewpoint of the sketch is both 'Boz' and the reader, whom 'Boz' asks to play along with imagining that they are attending the dinner, for which "you have a distinct recollection ... that you purchased a ticket at the solicitation of some charitable friend" (164). The use of "you" here creates a sense of shared disgruntlement on the part of 'Boz' and the reader at this anonymous friend's fatal persuasiveness. Dickens's use of the dramatic present tense ("The first thing that strikes you, on your entrance, is the astonishing importance of the committee" [164]) directs the reader's attention where he wants it to go. Comic detail is extremely important in the development of the sketch's shared world, where the reader is asked to recognize with 'Boz' the repetition of common social dilemmas and annoyances, such as the moment when "[h]aving deposited your hat and cloak, and received a remarkably small scrap of pasteboard in exchange (which, as a matter of course, you lose, 
before you require it again), you enter the hall. ..." (164). Yet the representation of the reader is as confusing as the representation of 'Boz'. The humour comes from shared experience, the conspiratorial "you" that means "you, me, all of us," but at the same time the existence of the sketch is premised on the reader's inexperience. As the dinner gets going 'Boz' tells us that " $[y]$ ou turn round to take a look at the table behind you, and - not being in the habit of attending public dinners - are somewhat struck by the appearance of the party on which your eyes rest" (164). Here, it is the reader's implied lack of knowledge of such occasions which provides the need for, and more importantly the possibility of, a detailed comic description of the fellow-guests by the wordly-wise sketch writer. The relationship between 'Boz' and his reader is at once symbiotic, and unstable.

The title "Public Dinners" points to the issues of spectacle and observation at play in the sketch and its subsequent illustration. 'Boz' is on public display here, as a writer, but also as a visual image realized by Cruikshank. The process of developing a relationship with readers was in many ways a painful one for Dickens: the constant drive to produce words, and his taxing Readings, were physical demands that likely contributed towards Dickens's relatively early death. ${ }^{32}$ The process of authorial branding carries within its semantic history the very physical meaning of a brand as a visual mark inflicted with hot iron, a mark which declares to the world (or those who can read and interpret the brand) that you are owned by somebody ("brand, n." $O E D$ ). Dickens and his visual image became a piece of property which, like Byron's or Egan's (or indeed Cruikshank's) may have belonged to him, but also belonged to the public. ${ }^{33}$

'[B]rand Boz' evolved unevenly into 'brand Dickens' (Patten, “Boz” 326) and Dickens kept re-inventing himself; images of Dickens, not 'Boz', seem to illustrate visually a shift in emphasis. Dickens made strenuous efforts to gain recognition for the work of the writer at the expense of the work of the illustrator, and instead of there being any sense of a team effort, of Dickens represented with one of his illustrators, the majority of later portraits show Dickens on his own. The lone body of the individual genius becomes the key focus again: even in the famous photograph of Dickens supposedly in the middle of a Public Reading, we don't see any audience, any public. Of course, the work of his illustrators is implicitly present in Robert Buss's watercolour of Dickens in his writing chair: the painting can only show Dickens's characters visually, not textually (Figure 13). Here it is not the body of the author that authenticates Dickens as the creator of much-loved characters but the images of the characters themselves, in a way which draws attention to how much Dickens's characters emerged from the reader's experience of the illustrations as well as the text. ${ }^{34} \mathrm{We}$ see here a combination of the two strategies of visual Byronism: the author set apart from, and yet simultaneously surrounded by, the bodies of his characters. But there is a crucial difference: that the painting is unfinished suggests a way in which the seated author is sharing an experience with his readers, using imagination to give moving bodies to characters.

Dickens's particular chair, as much as the body of the man in it, became a key part of the visual iconography of Dickensian authorship later in his life. Curtis has noted how the studies, desks, and chairs of both authors and artists become popular subjects for images of creative activity by the second half of the nineteenth-century; "[ $t]$ he writer's study was a significant location in the Victorian conception of the author" (189) as a newly-professionalized being (a professionalization largely due to the influence of Dickens). Figure 14 is William Frith's 1859 study of Dickens seated in his chair at one of his London homes. The older Dickens is depicted as a mature man of letters, facing away from his desk crammed with the 


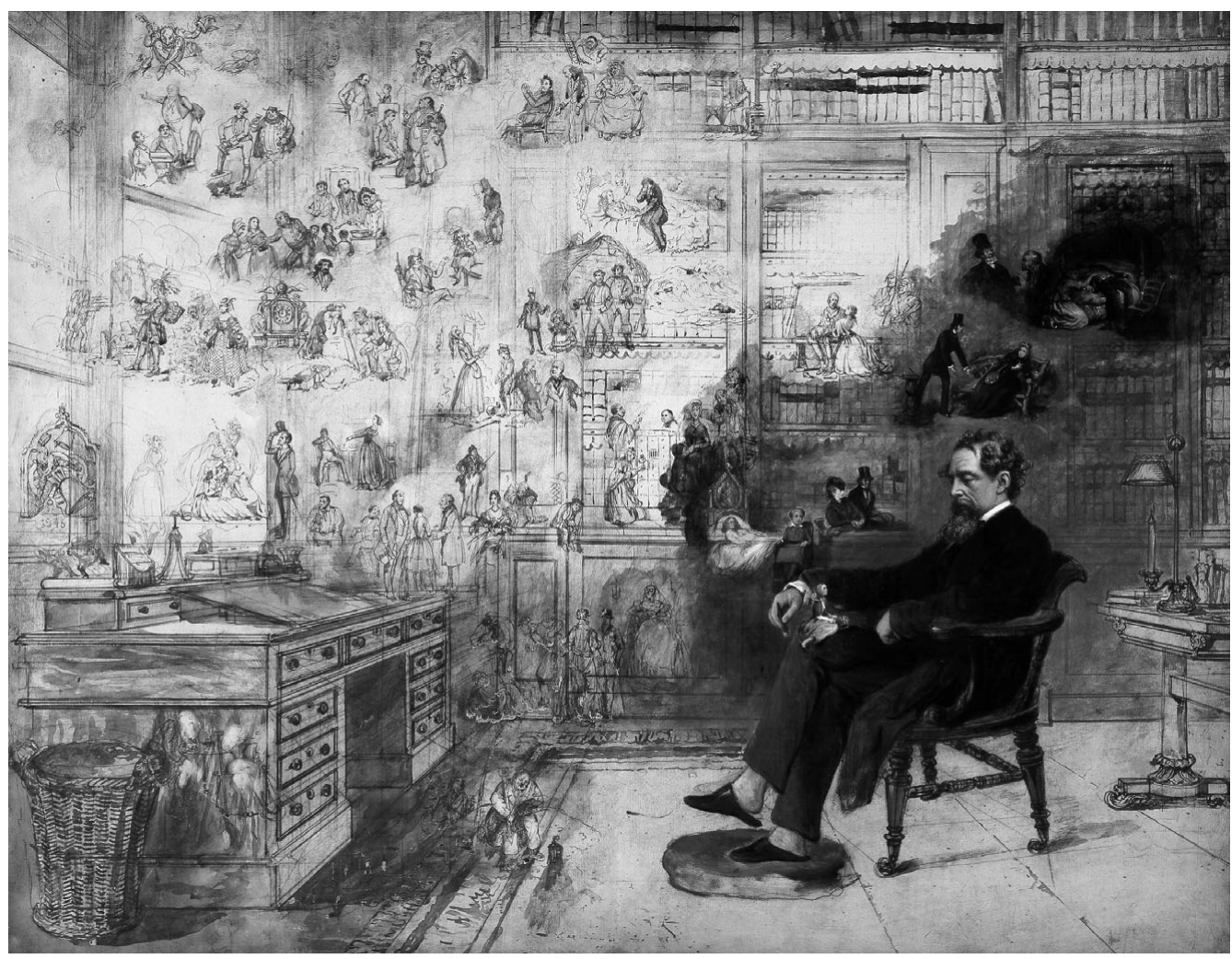

Figure 13. R. W. Buss. Dickens's Dream (1875). Unfinished watercolour. Charles Dickens Museum, London.

tools of his trade. Unlike Cattermole's sketch, his pose is languid, staring off into the distance as he muses on inspired ideas, although there is something of the Byronic dreaminess in his abstracted gaze. ${ }^{35}$ This is a Dickens who has finally found his own chair, and can use his own name.

For all his success, however, it seems that there may be something rather alarming about Dickens's chair when compared with Byron's. In the aftermath of public shock at Dickens's death, Luke Fildes (illustrator of Dickens's incomplete final novel The Mystery of Edwin Drood) painted a famous image of Dickens's empty chair in his study at Gad's Hill (Figure 15), which circulated widely in slightly-modified print form in the periodical press. Curtis's reading of this image, while productive, does not fully explain its power or its significance: this becomes clearer when set against Dickens's pre-Victorian models of celebrity authorship. For Curtis, "the image was not meant to stress so much the absence of the man Dickens, but, as the focus on the writing desk indicates, the absence of the writer Dickens, and of the hand that wrote" (190). The lack of any physical image of Dickens in the painting shows that he had transcended his visual branding and "been absorbed into his place of labour" (191). In other words, in a terrifying Gothic twist to this outwardly rather 


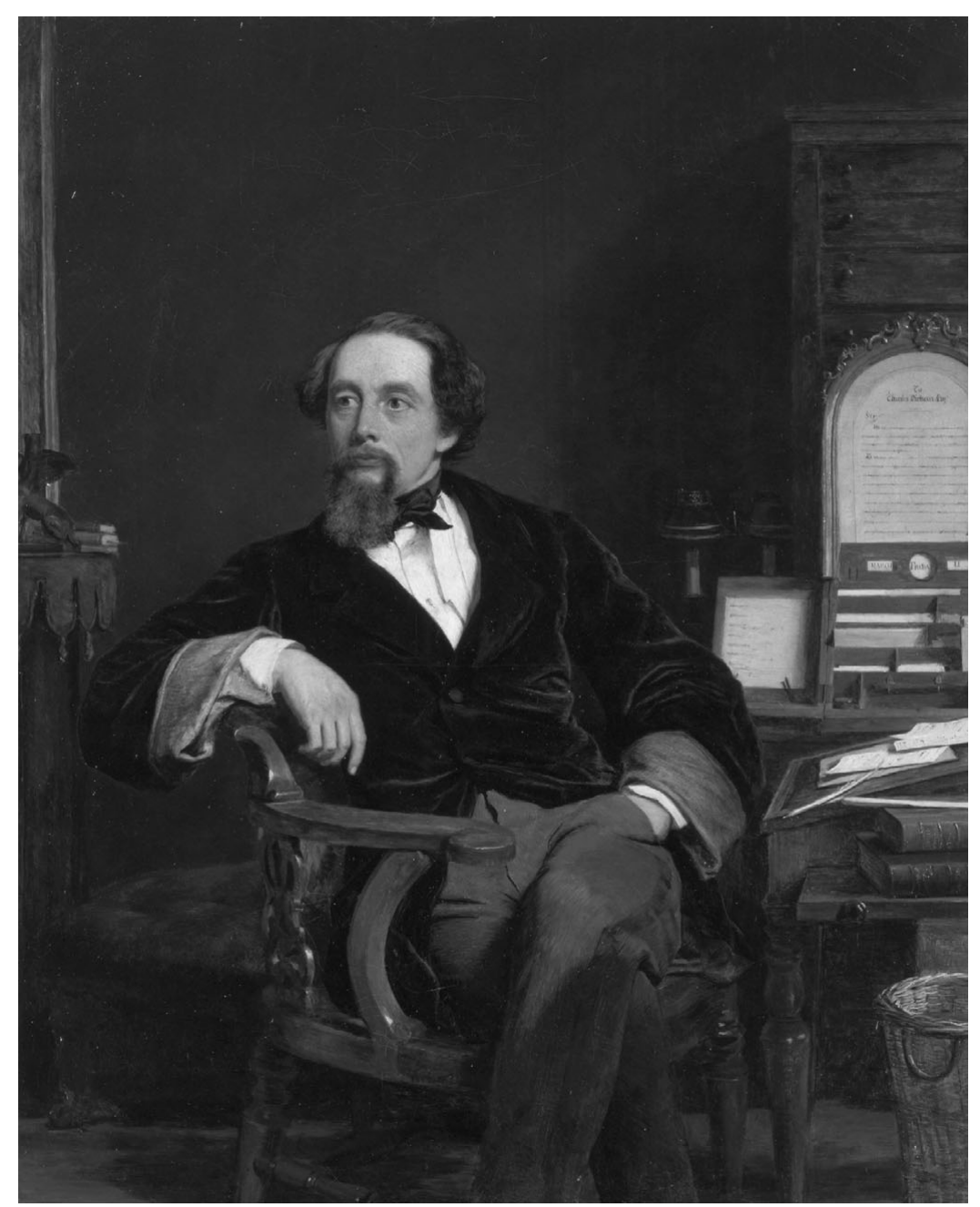

Figure 14. William Powell Frith. Charles Dickens in His Study at Tavistock House (1859). Oil. () Victoria and Albert Museum, London.

sentimental painting, Dickens the writer was embodied in his texts, and finally, became his chair:

Dickens was a forerunner of this paradigm shift in textual/image perception. His stated desire to promote the man of writing ... led to his being absorbed by the very mechanisms he had helped to set in motion ... Dickens's occupation and desk are now his entity ... (194)

This account of the dehumanized author is, in many ways, a convincing one. Indeed, Byron's chair became a site of sociability and creative exchange even after his death; owned by an artist, and sat on by a writer, the chair is depicted in use at a social gathering. By contrast, 


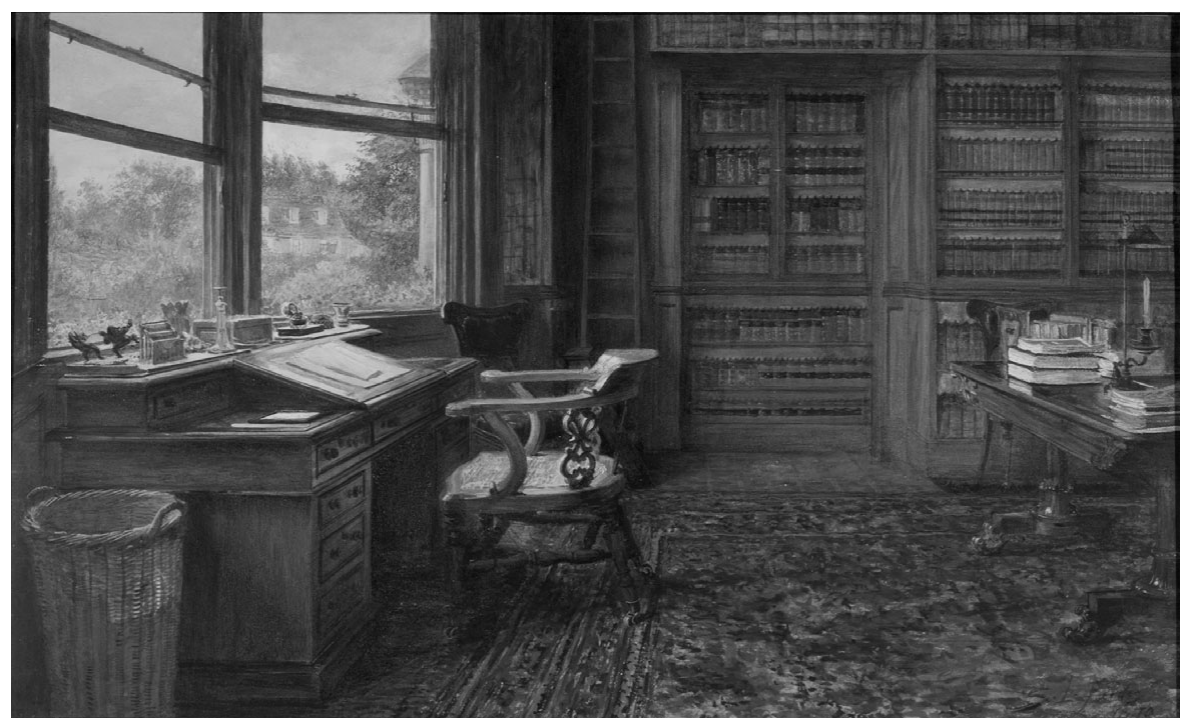

Figure 15. Samuel Luke Fildes. The Empty Chair. 1870. Watercolour on paper. Free Library of Philadelphia, Rare Book Department.

marooned on its own in an empty study in Fildes's painting, Dickens's chair appears invested with no such creative afterlife.

Fildes's The Empty Chair, however, shifts the site of creativity away from the author's body and towards the minds of the readers. Cattermole's sketch of Dickens in Byron's chair already, as I said earlier, abstracts the figure of the writer (in this case Byron) as an inanimate object: the chair. Byron is both present and absent in the sketch, and the fact that this abstraction has occurred as early as the 1840s (when Dickens is still a young man) disrupts the timeline of Curtis's otherwise convincing narrative. The very emptiness of Dickens's chair is indeed where the significance of Fildes's painting resides, but not just as a terrifying representation of a writer's absorption into an inanimate object. The painting relies for its emotional pull upon the very notion of the cultural importance of readers developed by Dickens himself through his language and his use of his own image. It is only readers of Dickens for whom the empty chair of the author would have any pathos or significance, as the missing body of the author-as-friend is registered, along with frustration at the inevitable cessation of any more creative works from his pen. Fildes was plagued by enthusiasts trying to track down the ending of Drood, itself a novel about a missing body, but had no new clues to add (Fildes 16, 175; Cohen 228); his painting seems to register something of the illustrator's lack of closure, too. The line of creative inheritance ends here: there is no up-andcoming young author, it seems, brave enough or talented enough to sit in this dead writer's chair. But in a move away from Byronic iconography, regenerative potential is now invested in Dickens's readers, not in any potential successor. The empty chair opens up a space of cultural consciousness for readers to fill with their own imaginations.

University of Roehampton, London 


\section{NOTES}

With grateful thanks to Robert L. Patten, Louis James, Maria Damkjaer and Paul Schlicke for comments on drafts of this essay, and to members of the Romantic Illustration Network who heard the first version at a symposium 'The Artist and the Writer,' Senate House, November 2014.

1. For more on the illustrations to Sketches, see Miller.

2. See Long on the Maclise portrait (http://www.npg.org.uk/collections/search/portraitLarge/mw01842/ Charles-Dickens) and its use as a frontispiece to Nickleby; Patten also discusses it at length ("Boz" 217-25).

3. Portraits of Charles Dickens (1812-1870) is an interesting online resource which has collected together images of Dickens.

4. See, for example, Patten, "Dickens as Serial Author" and "Boz" (152). Chittick has called the pseudonym Boz a 'trademark' (Chittick 57).

5. The status of book illustrators slipped over the course of Dickens's career, so much so that in 1872 Cruikshank felt the need to issue an angry pamphlet asserting his claim to be joint originator of popular works by William Harrison Ainsworth (Cruikshank). See also Meisel 282 on Cruikshank and Dickens, and Thackeray 53-54 on Cruikshank and Ainsworth.

6. See John, and Shannon.

7. It was Cruikshank who chose the subjects of the illustrations to Sketches, although he and Dickens did consult (Patten, Cruikshank 13-17, 30).

8. Dickens told Forster that "Boz was a very familiar household word to me, long before I was an author, and so I came to adopt it" (Forster, Life I: 59).

9. Dickens was first revealed as 'Boz' in print in 1836 (Patten, "Boz” 38).

10. See Douglas-Fairhurst figures 15, 20, 21, 25. Also the Maclise portrait, which features a chair not unlike Byron's.

11. See Curtis on writers' chairs (189-95), discussed in the final section of this article. Portraits of celebrity figures were not a new idea in the nineteenth-century: Marsh and D'Arcy Wood have discussed how images of actors David Garrick and Sarah Siddons demonstrate the connection between eighteenthcentury visual culture and the rise of modern celebrity (Wood 17-46).

12. "Scott is always to be found at the centre of any understanding of early-nineteenth century literary life: to understand Dickens's ambitions in his early manhood is to come round inevitably to Scott" (Chittick 18). See also Patten, "Boz" 13, 301. There was, of course, a visual dimension to Scott's fame as an author: according to Curtis's rough estimates of portrait originals, with some being drawings for engravings, 'Wordsworth and Scott were featured in 87 and 170 portraits respectively' (Curtis 151). However, the one portrait of Scott which draws upon Byronic iconography, by Thomas Phillips, was criticised by Scott's biographer for its 'theatrical air'. (Walter Scott Digital Archive).

13. "Images of authors had of course appeared in texts for centuries" (Patten, "Boz" 367 n. 91). Patten cites a contemporary example of Duncombe's 1835 edition of the complete plays of Douglas Jerrold.

14. There were different cultural anxieties about the potential public visibility of female authors: see Shires on Elizabeth Barrett Browning.

15. Dick Swiveller (The Old Curiousity Shop) and Mr Turveydrop (Bleak House) are comic Dickens characters given to quoting Byron. See Harvey.

16. This rise of a European "multinational culture industry" is identified by Mole as a key aspect of the new celebrity culture of the early-nineteenth century (Mole, Introduction to Romanticism and Celebrity Culture 7).

17. "Like Byron, he awoke one morning and found himself famous, and for a similar reason: for, however dissimilar the men and their works, both were originals and introduced a new style of writing" ("ART. IV.- Oliver Twist; or, the parish boy's progress" 84).

18. Interestingly Long wonders if, for some contemporary viewers, the Maclise frontispiece's "strongest impact may have been to convey the physical attractiveness of its subject" (51). 
19. See Mole, Byron's Romantic Celebrity 18, for discussion of the visual element in creating a "branded identity" for early-nineteenth century writers.

20. For the tension between literary 'celebrity' and 'genius' (notably in the figure of Byron) in the earlynineteenth century, see Higgins. For a useful discussion of literary 'lionism' as a meeting-point between print culture and visual culture, see Salmon.

21. See Sha.

22. The notion of the celebrity artist was of course not a new one: see Marsh on Joshua Reynolds (99).

23. Connections of style and content between Life in London and Sketches - and other early Dickens have been explored convincingly by Dart and Reid; Dart has placed 'Boz' alongside Egan as part of a growth in lower-middle class literature that he calls the "Cockney Moment", while Reid declares that "it is curious how many aspects of London life already described by Egan the young Dickens elected to write about" (Dart, Metropolitan Art and Literature; Reid 209).

24. See Hindley; Dart, "Flash Style"”; Maidment 216-18; Vincent.

25. This plate was probably done by his brother Robert, according to Patten, Cruikshank 227.

26. For contemporary gossip on this questions, see Hindley xiv; see also Patten, Cruikshank 223, and Reid 55.

27. Playbill, "Tom and Jerry", Wednesday, 25 Sept. 1822. Victoria \& Albert Museum Theatre and Performance Archive. Sadler's Wells production files, 1813-29, Box 1965.

28. See Shannon, and John. Andrews argues that Dickens's Readings were the next logical step from the "intimate" writing style which Dickens developed from the 1830s onwards and were directly enabled by it (Andrews 9-30).

29. See Collins. It is particularly apparent in what Juliet John calls Dickens's “"personal' journalism” (John 120).

30. See Schlicke on Dickens's complex use of personal pronouns across his career.

31. See Mole on Byron's readers and the "hermeneutic of intimacy", or a sense of intimate relationship between writer and reader, created by his poems (Byron's Romantic Celebrity 23).

32. See Small.

33. See Curtis on the appropriators of Dickens's image for satirical or commercial means (163-68).

34. Or as Buss may have liked to have illustrated them: see Cohen 58.

35. Contrast with Watson Gordon's posthumous portrait of Scott busy in his study (Walter Scott Digital Archive), and with the engraved version of the Maclise portrait for the Nickleby frontispiece, where, as Patten points out, "[n]othing about this frontispiece speaks about Dickens earning a living with his pen" (Patten, "Boz" 220).

\section{WORKS CITED}

Andrews, Malcolm. Charles Dickens and his Performing Selves: Dickens and the Public Readings. Oxford: OUP, 2006.

Anon. "ART. IV.- Oliver Twist; or, the parish boy's progress". Quarterly Review 64.127 (1839): 83-102. British Periodicals Online. Web. 9 Feb. 2014.

"authenticity, n." OED Online. Dec. 2014. OUP. Web. 18 July 2016.

"brand, n." OED Online. Dec. 2014. OUP. Web. 9 Feb. 2015.

Carlisle, Janice. The Sense of an Audience: Dickens, Thackeray, and George Eliot at Mid-Century. Athens: U of Georgia P, 1981.

Chittick, Kathryn. Dickens and the 1830s. Cambridge: CUP, 1990.

Cohen, Jane R. Charles Dickens and his Original Illustrators. Ohio: Ohio State UP, 1980.

Collins, Philip, ed. Charles Dickens: The Critical Heritage. London: Routledge, 1971.

Cruikshank, George. The Author and the Artist. London: Bell and Daldy, 1872. 
Curtis, Gerard. Visual Words. Aldershot: Ashgate, 2002.

Dart, Gregory. "'Flash Style"”: Pierce Egan and Literary London'. History Workshop Journal 51 (Spring 2001): 180-205. JSTOR. Web. 9 Feb. 2014.

Dart, Gregory. Metropolitan Art and Literature, 1810-1840: Cockney Adventures. Cambridge: CUP, 2012.

Dickens, Charles. "Horatio Sparkins." Sketches by Boz. The Dent Uniform Edition of Dickens' Journalism: Sketches by Boz and Other Early Papers, 1833-39. Ed. Michael Slater. Illus. George Cruikshank. London: J. M. Dent, 1994. 345-58.

Dickens, Charles. Letter to Richard Bentley, 2 November 1836. The Pilgrim Edition of the Letters of Charles Dickens: Volume One 1820-1839. Ed. Madeline House, Graham Storey and Kathleen Tillotson. Oxford: Clarendon Press, 1965. 189-90.

Dickens, Charles. Pictures From Italy. Ed. Kate Flint. Harmondsworth: Penguin Classics, 1998.

Dickens, Charles. Preface. Sketches by Boz. The Dent Uniform Edition of Dickens' Journalism: Sketches by Boz and Other Early Papers, 1833-39. Ed. Michael Slater. Illus. George Cruikshank. London: J. M. Dent, 1994. xxxix.

Dickens, Charles. "Public Dinners," from Sketches by Boz. Ed. Michael Slater. 162-67.

Dickens, Charles. Sketches by Boz. Ed. Dennis Walder. London: Penguin Classics, 1995.

Egan, Pierce. Life in London. Illus. Robert and George Cruikshank. London: Sherwood, Neely and Jones, 1821.

Douglas-Fairhurst, Robert. Becoming Dickens: The Invention of a Novelist. Cambridge, Mass.: Belknap Press of Harvard UP, 2011.

Fisher, Judith. "Image versus Text in the Illustrated Novels of William Makepeace Thackeray." Victorian Literature and the Victorian Visual Imagination. Eds. Carol T. Christ and John O. Jordan. Berkeley: University of California Press, 1995. 60-87.

Forster, John. The Life of Charles Dickens. 2 vols. London: Chapman \& Hall, 1911; 1st published 1872-74.

[Forster, John.]. "Theatrical Examiner." Examiner 11 Dec. 1836: 792. Web. 9 Feb. 2015.

Harvey, W.R. "Charles Dickens and the Byronic Hero." Nineteenth-Century Fiction 24.3 (Dec. 1969): 30616. JSTOR. Web. 9 Feb. 2015.

Higgins, David. "Celebrity, Politics and the Rhetoric of Genius." Romanticism and Celebrity Culture. Ed. Tom Mole. 41-59.

Hindley, Charles. True History of Tom and Jerry. London: Reeves \& Turner, 1890.

John, Juliet. Dickens and Mass Culture. Oxford: OUP, 2010.

Layard, George Soames. George Cruikshank's Portraits of Himself. London: W.T. Spencer, 1897.

Long, William F. "An Irreverent Contemporary Comment on the Impact of the Nickleby Portrait." Dickensian 112. 498 (Spring 2016): 46-53.

Maclise, Daniel. Charles Dickens. 1839. Oil on canvas. National Portrait Gallery, London. http://www.npg. org.uk/collections. Web. 18 July 2016.

Maidment, Brian. Comedy, Caricature and the Social Order, 1820-50. Manchester: Manchester UP, 2013.

Marsh, Joss. "The Rise of Celebrity Culture." Charles Dickens in Context. Ed. Sally ledger and Holly Furneaux. Cambridge: CUP, 2011. 98-108.

Meisel, Martin. Realizations: Narrative, Pictorial, and Theatrical Arts in Nineteenth-Century England. Princeton: Princeton UP, 1983.

Miller, J. Hillis. "The Fiction of Realism: Sketches by Boz, Oliver Twist, and Cruikshank's Illustrations." Dickens Centennial Essays. Ed. Ada Nisbet and Blake Nevius. Berkeley and London: U of California $\mathrm{P}, 1971.85-153$.

Mole, Tom. Byron's Romantic Celebrity: Industrial Culture and the Hermeneutic of Intimacy. Basingstoke: Palgrave Macmillan, 2007.

Mole, Tom. Introduction. Romanticism and Celebrity Culture, 1750-1850. Ed. Tom Mole. Cambridge: CUP, 2009. 1-17.

Patten, Robert L. Charles Dickens and "Boz": The Birth of the Industrial-Age Author. Cambridge: CUP, 2012. 
Patten, Robert L. "Dickens as Serial Author: A Case of Multiple Identities." Nineteenth-Century Media and the Construction of Identities. Ed. Laurel Brake, Bill Bell, and David Finkelstein. Basingstoke \& New York: Palgrave, 2000. 137-53.

Patten, Robert L. George Cruikshank's Life, Times, and Art. London: Lutterworth P, 1992. 2 vols.

Playbill. "Tom and Jerry." Wednesday, 25 Sept. 1822. Victoria \& Albert Museum Theatre and Performance Archive. Sadler's Wells Production Files, 1813-29. Box 1965.

Portraits of Charles Dickens. http://photohistory-sussex.co.uk/DickensCharlesPortraits.htm. Web. 18 July 2016.

Reid, J. C. Bucks and Bruisers: Pierce Egan and Regency England. London: Routledge, 1971.

Salmon, Richard. "The Physiognomy of the Lion: Encountering Literary Celebrity in the Nineteenth Century." Romanticism and Celebrity Culture, 1750-1850. Ed. Tom Mole. Cambridge: CUP, 2009. 60-78.

Schlicke, Paul. "Our Hour: Dickens's Shifting Authorial Personae." Charles Dickens and the Mid-Victorian Press. Ed. Hazel Mackensie and Ben Winyard. Buckingham: Buckingham UP, 2013. 261-75.

Sha, Richard C. The Visual and the Verbal Sketch in British Romanticism. Philadelphia: U of Pennsylvania $\mathrm{P}, 1998$.

Shires, Linda. "The Author as Spectacle and Commodity: Elizabeth Barrett Browning and Thomas Hardy." Victorian Literature and the Victorian Visual Imagination. Ed. Carol T. Christ and John O. Jordan. Berkeley: U of California P, 1995. 198-212.

Slater, Michael. Charles Dickens. New Haven and London: Yale UP, 2009.

Shannon, Mary L. Dickens, Reynolds and Mayhew on Wellington Street: The Print Culture of a Victorian Street. Farnham: Ashgate, 2015.

Small, Helen. "A Pulse of 124: Charles Dickens and a Pathology of the Mid-Victorian Reading Public." The Practice and Representation of Reading in England. Ed. James Raven, Helen Small, and Naomi Tadmor. Cambridge: CUP, 1996. 263-90.

St Clair, William. The Reading Nation in the Romantic Period. Cambridge: CUP, 2004.

St Clair, William. "Image and Word: Towards a Political Economy of Book Illustration." Romantic Illustration Network Symposium. The British Academy, London, 6 July 2014.

Thackeray, W.M. "George Cruikshank." Westminster Review 34.1 (June 1840): 4-60. British Periodicals Online. Web. 9 Feb. 2015.

Vincent, David. I Hope I Don't Intrude: Privacy and its Dilemmas in Nineteenth-Century Britain. Oxford: OUP, 2015.

Walter Scott Digital Archive. http://www.walterscott.lib.ed.ac.uk/home.html. Web. 14 Dec. 2015

Wood, Gillen D'Arcy. The Shock of the Real: Romanticism and Visual Culture, 1760-1860. Basingstoke: Palgrave, 2001. 